\title{
ОСНОВНІ ПРИНЦИПИ КЛАСИФІКАЦІЇ КВАЗІКОМПОЗИТІВ (НА МАТЕРІАЛІ УКРАЇНСЬКОЇ, РОСІЙСЬКОЇ, АНГЛІЙСЬКОЇ ТА ФРАНЦУЗЬКОї МОВ)
}

Самойленко О. В. Основні принципи класифікації квазікомпозитів (на матеріалі української, російської, англійської та французької мов).

У статті аналізуються можливі підходи до класифікації квазікомпозитів, порівнюються основні критерії класифікацій таких одиниць 3 принципами групування складних слів. Дослідниця доводить, що квазікомпозити можуть розподілятися за тими ж ознаками, що й власне складні слова, але й існують певні відмінності, які також розглядаються у роботі.

Ключові слова: власне складні слова, квазікомпозити, ендоцентричні складні слова, екзоцентричні композити, копулятивні складні слова, аппозитивні композити, координативний зв'язок, субординативний зв'язок.

Самойленко Е. В. Основные принципы классификации квазикомпозитов (на материале украинского, русского, английского и французского языков).

В статье анализируются возможные подходы к классификации квазикомпозитов, сравниваются основные критерии классификации таких единиц с принципами группирования сложных слов. Исследовательница доказывает, что 
квазикомпозиты можно классифицировать по тем же признакам, что и собственно сложные слова, но существуют и определённые отличия, которые также рассматриваются в работе.

Ключевые слова: собственно сложные слова, квазикомпозиты, эндоцентрические сложные слова, экзоцентрические сложные слова, копулятивные композиты, аппозитивные сложные слова, координативная связь, субординативная связь.

Samoylenko E. V. The main principles of quasi-composites classification (on the material of Ukrainian, Russian, English and French).

In the article possible approaches to the classification of quasicomposites are analyzed, the main criteria of classification of such units with the principles of compound words differentiating are compared. The investigator proves that quasicomposites may be classified according to the same signs as proper compound words, but there are some differences which are also under consideration in this work.

Key words: compound words proper, quasicomposites, endocentric compound words, exocentric compound words, copulative composites, appositive compound words, coordinative link, subordinative link.

Композити та словоскладання як продуктивний спосіб словотвору давно привертали увагу філологів. Представники різних лінгвістичних шкіл та течій пропонували свої класифікації складних лексем, що базуються на семантиці, структурних особливостях, співвідношенні між елементами складного слова, ідіоматичності / неідіоматичності, механізмі творення тощо. У нашій роботі ми розглядаємо квазікомпозити, а ця стаття - спроба перенести принципи класифікації складних слів на квазікомпозити. Під цим терміном слідом за В.І. Теркуловим ми будемо розуміти одиниці. які утворилися не шляхом конденсації одиниць синтаксичного рівня (словосполучень або речень), а за продуктивними моделями, які вже функціонують у мові. Саме вибір об'єкту дослідження (квазікомпозити української, російської, англійської та французької мов) зумовив актуальність наукової праці, бо квазікомпозити вивчалися тільки у протиставленні та порівнянні 3 власне композитами, тому майже не існує спроб класифікації таких лексичних одиниць.

Мета нашого дослідження - установлення можливих шляхів класифікації квазікомпозитів. Для іiі реалізації розв'язували такі завдання: 1) установити основні можливі критерії класифікації квазікомпозитів; 2) порівняти ці принципи з основними критеріями класифікації власне складних слів; 3) довести, що власне складні слова та квазікомпозити мають однакові принципи класифікації; 
4) проаналізувати відмінності у класифікаціях власне складних слів та квазікомпозитів.

Для чіткого визначення поняття квазікомпозит необхідно звернутися до класифікації складних слів за типом відношень між компонентами твірної одиниці, яку в 70-х роках $\mathrm{XX}$ ст. розробив В. О. Горпинич. Він виділяе три різновиди основоскладання: 1) утворення похідних слів на базі сурядних синтаксичних словосполучень: ліс $i$ тундра - лісотундра, фізика $і$ математика фізико-математичний; 2) утворення похідних слів на базі підрядних синтаксичних словосполучень: народне господарство народногосподарський, n'ять років - n'ятирічний, добувати вугілля вугледобувний; 3) утворення похідних на базі слів, що безпосередньо не поєднуються в синтаксичні словосполучення: атомохід, тепловоз, авіапошта, радіоательє, фотогазета [4, с. 88]. Саме ця класифікація стає одним із перших доказів неспроможності суто синтаксичного підходу до творення складних слів.

О. С. Кубрякова у своєму науковому доробку також торкається цієї проблематики: вона розрізняє три типи словотвірних процесів аналогічний, що спирається на наявний лексичний зразок (влаголюбивый - за аналогією до светолюбивый, танкодром - за аналогією до аеродром), кореляційний, в основі якого знаходиться аналогія більш складного типу (латинский: латинист = германский : $\mathrm{x}$, где $\mathrm{x}$ - германіст), та синтактичний (дефініційний), при якому слово мотивується не словом, а судженням, висловлюванням, яке містить дефініцію відповідного предмету [6]. Аналогія - це синтаксичний процес, при якому мовні одиниці або категорії на основі певної схожості, схожої форми, значення та функціонування отримують можливість подальшого єдиноспрямованого, паралельного розвитку або ж повної уніфікації однієї одиниці (категорії) за зразком іншої Утворення за аналогією нагадує процес розв'язання пропорційного рівняння, коли на основі певної кореляції між двома (кількома) одиницями або формами однієї одиниці повинна мати місце і в іншому співвідношенні між ними в одному будьякому відношенні така ж або подібна кореляція.

Ураховуючи значення аналогії для розвитку мовної системи, B. I. Теркулов [12] пропонує детальну двоярусну класифікацію композитів та власну термінологію. Перший ярус констатує різницю між синтаксичними композитами, тобто композитами, що утворилися шляхом конденсації словосполучень за моделями, що вже функціонують у певній мові, та аналогічних композитів (або 
квазікомпозитів), тобто лексичних одиниць, які утворилися за аналогією $з$ синтаксичними композитами на базі слів, що не пов' язуються в синтагмі.

Синтаксичними композитами будуть виступати такі лексеми, як фp. voyage-fleuve (лексична одиниця утворилася на базі словосполучення un voyage fleuve), англійський іменник bookselling, який утворився шляхом конденсації словосполучення sell books, українське слово звуконаслідування, базою якого виступає утворення наслідування звуків, російський композит длинноногий, що виник на базі словосполучення $c$ длинными ногами. До аналогічних композитів слід віднести, наприклад, французьку лексему autopoтpe, англійську clockwise, російську аеросев, українську гей-naтi, які явно складаються 3 двох конструктів, але не мають при цьому ніякого словосполучення як джерела.

Другий ярус класифікації передбачає підрозділ синтаксичних та аналогічних композитів на дві підгрупи: універбалізаційні композити та дериваційні композити.

Для рівня синтаксичних композитів В. І. Теркулов виділяє синтаксичні універбалізаційні та синтаксичні дериваційні композити. Під універбалізаційними композитами вчений розуміє складні слова, що виникли як вербальні еквіваленти словосполучень i внаслідок цього функціонально i семантично їм тотожні, наприклад, велоспорт (велосипедный спорт), широкоплечий (с широкими плечами), нефтедобыча (добыча нефти), a pencil-box (a box for pens), a blackbird (a black bird), coffre-fort, m ( un coffre-fort), arc-en-ciel, m (un arc en ciel), cáchené, m (cácher le né). Слід погодитися 3 думкою Є. М. Сидоренко, що універбалізація - «це не словотвірний прийом і не словотворчий мовний засіб, а вираження тенденції до усунення розбіжності між єдністю значення та розчленованістю форми лексичної одиниці, яке використовує різні словотвірні прийоми» [9].

Під дериваційними композитами ми розуміємо одиниці, семантика яких складається з семантики базового словосполучення та семантики форманта (тобто словотворчого афікса): англ. Barefooted $(<$ bare foot + продуктивний афікс -ed), рус. белобилетник $(<$ бельій билет + формант -ник), укр. босоніжка (<босі ноги + формант -к $(a)$.

Теорію В. І. Теркулова було поширено на квазікомпозити О. В. Блюміною. Ми, слідом за нею, виділяємо два типи квазікомпозитів: квазікомпозит 3 дериваційною домінантою та квазікомпозит з універбалізаційною домінантою. У першому разі квазікомпозит імітує кінцеву структуру дериваційного композиту. Наприклад, квазікомпозит моторостроение утворився від лексеми 
мотор за допомогою галузевого конструкта - строение як імітація структури дериваційних композитів домостроение (строить дома + формант -ение), кораблестроение (строить корабли + формант -ение). У другому разі творення квазікомпозитів грунтується на аналогічній імітації кінцевої структури універбалізаційних композитів. Наприклад, квазікомпозит электротерапия виник як імітація структури універбалізаційних композитів музыкотерапия, який являє собою дублет коллокації музыкальная терапия, химиотерапия дублета химической терапии тощо (словосполучення електрическая терапия не можна визнати реальним прототипом, тому що воно $\epsilon$ вторинним по відношенню до складного слова, тобто виникає в результаті лексичного розгортання цієї лексеми в одиницю синтаксичного рівня і являє собою результат реетимологізації). У таких ситуаціях творення квазікомпозитів грунтується на аналогічній імітації кінцевої структури універбалізаційних композитів, наприклад, квазікомпозит бальнеотерапия виник як імітація структури універбалізаційних композитів музыкотерапия, яка виступає дублетом коллокації музыкальная терапия, химиотерапия - дублета химической терапии тощо (словосполучення бальнеологическая терапия навряд чи можна визнати реальним прототипом) [3]. Дослідниця робить спробу класифікувати квазікомпозити за критеріями власне складних слів, тому вважаємо за можливе поширити інші підходи стосовно класифікації композитів на псевдоскладні слова.

Представники різноманітних лінгвістичних течій та груп пропонують такі види класифікацій: 1) семантичну; 2) синтаксичну; 3) структурну; 4) частиномовну; 5) за типом словоскладання; 6) за механізмом утворення; 7) за типом мотивованості.

Семантична класифікація складного слова запропонована ще давньоіндійським лінгвістами: основним принципом, який покладено в іii основу, $\epsilon$ відношення композита загалом до його складових елементів. За цим критерієм можна виділити такі класи композитів / квазікомпозитів:

1. Ендоцентричні композити - складні слова, що складаються 3 ядра, тобто головної частини композиту, яка визначає його лексичне значення, та модифікатора, який звужує або уточнює це значення, тобто семантичне значення та граматичні функції композита або квазікомпозита чітко визначаються його складовими частинами. Наприклад, російський квазікомпозит бальнеотерапия, де терапия - це 
ядро, а бальнео- його модифікатор, що інформує нас про спосіб, за допомогою якого здійснюється певний захід, при цьому головний компонент визначає частину мови складного утворення та його можливі граматичні функції в реченні. До цього типу складних слів можна віднести й англійський квазікомпозит $A B C$-book, де book - це ядерна частина, що визначає клас предметів, до якого належить певний об'єкт, а елемент $A B C$ повідомляє нам про належність цієї книги до певного класу - підручників. Ця група квазікомпозитів $\epsilon$ найчисельнішою: укр. агродопомога, турбохід; англ. alpha-test, rainproof, parrot-fashion; poc. профосмотр, наркомания, галлофобия, культтовари; фр. situation-type, chantier-vedette, appartement-témoin.

2. Екзоцентричні складні слова - це лексеми, значення яких не виходить зі значення його складових елементів, до того ж при творенні цього типи складних / квазіскладних слів наявне переосмислення вихідної семантики основ, залучених до словоскладання, тобто номінація не зумовлюється відношеннями зовнішньої валентності одиницьскладових елементів. Значення цього типу складних слів визначається сукупністю смислів компонентів, що його утворюють. Для прикладу можна звернутися до англійський квазікомпозиту must-have. На відміну від компонентів, що входять до його складу (must - повинен, have - мати) - це не дієслово, а іменник зі значенням «можливий власник». До цієї ж групи слів можна віднести українські лексеми на зразок дурисвіт, загнибіда, песиголовець, голоштанько. Продуктивним такий спосіб словотвору $є$ і для квазікомпозитів у російській та англійській мовах: ротозей, горемька, тунеядеu, cablespeak, marketing-speak, nounspeak, machinespek, rubblehead, smackhead, thick-head, feedback. У французькій мові, де багато складних слів завдячують своєю появою процесам метафоризації, такий пласт лексики є особливо великим: cerf-volant, $\mathrm{m}$ дослівний переклад «олень, який літає», а використовується в значенні «повітряний змій»; chat-huant, m - дослівний переклад «кіт, який шипить» а використовується в значенні «лісова сова»; croque-mitaine, $\mathrm{m}$ складається $з$ елементів, які перекладаються українською мовою «гризи кота», але в сучасній французькій мові позначають пугало.

3. Копулятивні композити - складні слова, що мають два семантичні ядра, які $€$ рівноцінними. Вони характеризуються наявністю в кожного компонента окремого лексичного значення, що разом формують єдине значення композиту. Наприклад, український квазікомпозит лісотундра складається з двох окремих елементів ліс та тундра, які мають власне семантичне значення: ліс - велика площа землі, що заросла деревами і кущами та дерева, які зростають на такій 
площі, а тундра - це південна зона арктичного поясу земної кулі, безлісий простір з суворим кліматом, вічною мерзлотою, бідною рослинністю, серед якої переважають мохи й лишайники. Лісотундрою називають природну зону, яка є перехідною між зонами тундри та лісу, тобто лісотундра - це не сукупність або суміш лісу та тундри, а окрема природна зона, яка характеризується власними географічними та кліматичними ознаками. М. Д. Степанова визначає, що складові частини копулятивного композиту повинні належати до однієї частини мови і бути пов'язані між собою сурядністю, тобто обидва компоненти такого композита мають власне лексичне значення, але вони однаково залучені до формування значення складної лексичної одиниці, їх семантичне співвідношення може бути описано сурядним зв'язком «і, та» [11, с. 115], наприклад, укр. лавровишня, рос. зубробизон. До цієї групи можна віднести багато квазікомпозитів, тому що такі лексичні утворення важко розгорнути у відповідні словосполучення $з$ ідентичними семантичним значенням, адже значення, наприклад української лексеми жовтогарячий, не відповідає значенню словосполучення «жовтий та гарячий». До цієї групи слід віднести французькі квазікомпозити aigre-doux; англійські bittersweet, sour-sweet; російські - кисло-сладкий, горько-кисльй; українські - кисло-солодкий, гірко-солодкий, тобто лексеми на позначення смаку. Сюди належать також лексеми на позначення комбінованих кольорів: рос. жёлто-красный, сине-зелёный; укр. рожевобілий, фіолетово-синій; англ. yellow-red, blue-grey; фр. bleue-vert, rougeorange. Копулятивними $є$ квазікомпозити, що позначають складні назви сторін світу та похідні прикметники: рос. северо-запад, юго-восток; укр. північно-східнии, південно-західний; англ. South-east, North-west; фр. NordEst, Sud-ouest.

4. Аппозиційні складні слова (слова-прикладки), які забезпечують процес подвійної номінації, тобто для одного й того ж феномену наводяться дві назви: перший компонент називає ознаку предмета i водночас дає йому нову назву. Об'єкт при цьому характеризується 3 різних боків: англ. maidservant, actor-director; фр. canapé-lit, fille-pilotes; укр. диван-ліжко, дівчина-авіатор; poc. плащ-палатка, менеджер-экономист. Квазікомпозити цієї групи представлені гендіадісом, тобто римованими складними словами, що утворюються шляхом повтору дещо змінених компонентів (здебільшого на базі рими): фр. tohu-bohu, m, abra-cadabra; англ. 
helter-skelter, teeny-weeny; pос. фокус-покус, шурум-бурум; укр. козадереза, кохання-зітхання, супер-пупер.

Іншою досить поширеною класифікацією $є$ синтаксична, яку запропонував К. Нюроп [19]. Її сутність полягає у виділенні певного синтаксичного зв'язку між елементами складного слова. Мовознавець поділяє складні слова на та підрядні - субординативні (фр. subordination: timbre-poste) та сурядні - координативні (фр. coordination: chou-fleur).

Субординативні складні слова - це такі слова, це такі слова, кореневі морфеми у складі яких демонструють нерівноправність семантико-синтаксичних відношень. Тут можна виділити (на основі методу трансформації) головний та залежний компоненти, тобто ядро та модифікатор. У російській, українській та англійській мовах граматичне навантаження несе другий (останній) компонент. Він надає граматичного значення частини мови усьому слову та визначає його лексико-граматичний клас: змієподібний, веерообразный, Billygate. Але французькі композити досить часто мають правобічний базис: état-major, m, що пояснюється структурними особливостями французької мови.

У координативному композиті один із складових компонентів не має переваги над іншими. Обидва компоненти i структурно, i семантично до певної міри незалежні. Такі композити та квазікомпозити маніфестують асоціативність людського мислення під час наукової номінації. Компоненти цих складних слів належать, як правило, до однієї частини мови, мають приблизно однакові лексикосемантичні характеристики. Поділяються координативні композити так:

1) складені, що означають особу або предмет, який одночасно виконує дві або більше дії, має одночасні обов'язки або певні характерні риси тощо, наприклад, англ. souer-sweet; poc. звероящер; укр. жовтогарячий, лісотундра; фр. Nord-est;

2) редуплікативні, що повторюють одну основу: англ. goodygoody; укр. гарний-прегарний; рос. высоко-высоко; власне редупліковані слова не можуть бути квазікомпозитами: вони не творяться на основі словосполучень або речень, але, з іншого боку, не утворюються за певним зразком або сполученням основ 3 різним семантичним значенням;

3) фонетично різні римовані форми однієї основи: англ. walkie-talkie; poc. тяn-ляn; фр. meli-melo; укр. тяп-ляп.

Слідом за К. Нюропом більшість дослідників (І. В. Арнольд [2], Г. Марчанд [16], О. І. Смирницький [10], М. І. Мостовий [7]) 
вважають, що існує тільки два типа стосунків між компонентами складного слова. Але ми вважаємо, що необхідно виділити три типи стосунків між елементами композиту (більшість дослідників виділяє тільки два, забуваючи про деякі випадки функціонування гендіадісу, коли його констітуентні елементи в ізоляції гублять власне лексичне значення: фіглі-міглі, шуры-муры, pèle-mèle, mish-mash).

На наш погляд, доцільним було б виділити такі класи квазікомпозитів: координативні, субординативні та побудовані на взаємозалежності складових компонентів, які не існують у мові в якості самостійних лексем. Ми пропонуємо називати цю групу лексем гендіадісними.

I. В. Арнольд пропонує класифікацію за типом словоскладання: 1) юкстапозиція: англ. heart-felt; poc. люля-кебаб; фр. porte-fenètre; 2) слово / основоскладання за допомогою поєднувального голосного / приголосного: англ. speedometer; фр. cosmodrome; poc. англофобия; 3) композити 3 поєднувальним елементом, вираженим прийменником або сполучником: англ. son-in-law; фp. esprit-de-sel. Як бачимо, квазікомпозити можуть утворюватися шляхом юкстапозиції та слово / основоскладанням за допомогою з'єднувального голосного / приголосного, бо наявність поєднувального елемента, вираженого прийменником або сполучником, свідчить про конденсацію певного словосполучення у складне слово.

Згідно з семантикою складного слова, яка визначається усією сукупністю його парадигматичних та синтагматичних зв'язків (Ю. Д. Апресян, Е. М. Медникова) композити можна поділити на дві групи: неідіоматичні складні слова та ідіоматичні складні слова [1]. У групі неідіоматичних складних слів необхідно розрізняти композити 3 прямим значенням або власне неідіоматичні складні слова (значення таких слів виводиться із значень його компонентів), наприклад, англ. football; фр. Eurodollar, m; poc. дальнозоркость; укр. зіркоподібний, та складні слова 3 переносним значенням: метафоричні та метонімічні складні слова (cold-hearted, coure-feu, m). Більшість квазікомпозитів - неідіоматичні складні слова, але в англійській, російській та українській мовах можна зустріти певний пласт квазікомпозитів, що утворилися на базі метафори: англ. business-friendly, environment-friendly; poc. кукловод; укр. голоштанько. Узагалі, у композитології сучасної англійської мови метафора породжує нові оказіональні смисли структурно-складних термінів у сфері соціально-структурного спілкування. 
Цілком природно, що усі складні слова можна поділити за належністю до певної частини мови. В усіх мовах, які розглядаються в нашій роботі найчисельнішу групу складних слів (та квазікомпозитів) складають іменник $(77,3 \%)$, далі йдуть прикметники $(20,4 \%)$, а потім дієслова (2,6\%). Складні сполучники, прийменники й інші службові частини мови можна зустріти дуже рідко.

За типом мотивованості можна виділити повністю мотивовані квазікомпозити (іх значення витікає із суми значень їх компонентів, а внутрішня форма слова $€$ прозорою): рос. гльббообразный, электромобиль, авиамагистраль; укр. англоманія, авіадесант; англ. shock-proof, spider-like, water-intensive; фp. industrie-pilote, prix-choc; частково мотивовані квазікомпозити (лексеми, у яких помітним є зсув значення одного із компонентів, але пори певні зміни у семантичній структурі одного із компонентів, значення композита в цілому $\epsilon$ достатньо вмотивованим, прозорим): укр. Івинтокрил; рос. голодранец, ротозей; англ. stemware (келихи, чарки), seeware, tom-cat; фp. snowboard; немотивовані або ідіоматичні (семантика цих слів не відповідає окремим значенням їх структурних складників). На наш погляд, окрім ідіоматичних квазікомпозитів до останньої групи можна віднести англійській римований сленг, що мотивується значенням відповідної простої лексеми, на яку пропонується римований відповідник, бо без конкретних знань майже неможливо здогадатися про їх значення: sky-rocket (pocket, кишеня = небо + ракета), tomfoolery (jewellery, коштовності $=$ Том + тупість $)$, greengage $($ stage, сцена = зелений + запорука), greengages (wages, заробітна плата = зелені + запоруки) та власне сленг, що часто грунтується на асоціаціях: slugnutty (той, хто страждає на головокружіння), snakepen (сержант: змія + ручка), Tommy-rot (нонсенс, несінітниця).

Усі проаналізовані приклади квазікомпозитів дозволяють нам прийти до висновку, що такі одиниці можуть бути класифіковані за критеріями звичайних складних слів з певними зауваженнями.

Перспективою подальших досліджень у цьому напрямку може стати розробка структурної та ономасіологічної класифікацій квазікомпозитів та їх порівняння 3 відповідними класифікаціями власне складних слів.

\section{Література}

1. Апресян Ю. Д. Идеи и методы структурной современной лингвистики (краткий очерк) / Ю. Д. Апресян, - М. : Просвещение, 1966. - 302 с.

2. Арнольд И. В. Лексикология современного английского языка : учебник [для студ. высш. уч. завед.] / И. В. Арнольд. - М. : Высшая школа, 1986. - 296 с. 
3. Блюмина О.В. Субстантивные композиты со значеним процессуальности в русском языке : дисс. ... канд. филол. наук : 10.02.12. «Русский язык» / О. В. Блюмина. Горловка, 2010. - 406 с.

4. Горпинич В. О. Будова слова і словотвір / В. О. Горпинич. К. : Радянська школа, 1977. $-118 \mathrm{c}$.

5. Кубрякова Е. С. Семантика синтаксиса и некоторые проблемы теориии словообразования / Е.С. Кубрякова // Сборник научных трудов Московского государственного института иностранных языков им. Мориса Тореза. - 1977. - №112. C. $123-133$.

6. Кубрякова Е. С. Типы языковых значений. Семантика производного слова / Е. С. Кубрякова. - М. : Наука, 1981. - 199 с. - (АН СССР, Ин-т языкознания).

7. Мостовий М. І. Лексикологія англійської мови: [підручник для студентів ін-тів і фак. іноземної мови] / Мостовий М. І. - Харків : «Основа», 1993. - 255 с.

8. Селіванова О. О. Лінгвістична енциклопедія / О. О. Селіванова. - Полтава : Довкілля-К, 2010. - 864 с.

9. Сидоренко Е.Н. Морфология современного русского языка (части речи и контаминанты) : [учебн. пособие] : в 2-х ч. / Е. Н. Сидоренко. - Симферополь : Еліньо, 2003. - Ч. 2. - 165 с.

10. Смирницкий А. И. Лексикология английского языка: учебн. пособие [для студентов вузов] / А. И. Смирницкий - М. : Изд-во лит-ры на иностр. яз., 1956. - 364 с. (Библиотечка филолога).

11. Степанова М. Д. Теоретические основы словообразования в немецком языке: [учебн. пособие] / М. Д. Степанова, В. Фляйшер. - М. : Высшая школа, 1984. - 264 с.

12. Теркулов В. И. Композиты русского языка в ономасилогическом аспекте : дис. ... доктора филол. наук : 10.02.02 / Теркулов Вячеслав Исаевич. - Горловка, 2008. - 406 с.

13. Теркулов В. И. О разграничении процессов лексикализации и вербализации / В. И. Теркулов // Теоретические и прикладные проблемы русской филологии : научно-методический сборник. - Вып. ХІІ. : Ч. І. - Славянск : СГПУ, 2005.

14. Шанский Н. М. Лексикология современного русского языка / Н. М.Шанский. - М. : Просвещение, 1972. - 328 с.

15. Katamba F. English Words: Structure, History, Usage / F. Katamba. Routledge : Language Teaching and Research Press, 2005. - 282 p.

16. Marchand H. The Categories and Present-Day English Word-Formation / H. Marchand. - Munchen, 1969. - 427 p.

17. Matthews P. H. Morthology / P. H. Matthews. - Cambridge: Foreign Language Teaching and Research Press, 2001. -256 p.

18. Moraveshik E. A. Reduplicative constructions / E. A Moraveshik // Universals of Human Language. - 1978. - №3. - P. 297-334

19. Nyrop K. Das Leben der Worter / K. Nyrop. - Leipzig, 1903. - 244 p.

Стаття надійшла до редакції 12.09.2012 р. 